\title{
TOROUE SMOOTHING OF A FAULT TOLERANT SEGMENTAL STATOR SWITCHED RELUCTANCE MOTOR
}

The relatively high torque ripples are one of the main disadvantages of the switched reluctance motors. By smoothing their torque they can become more competitive for variable speed drives used in automotive and industrial applications. One of the most promising approaches to reduce the torque ripples of a SRM is the use of a direct instantaneous torque controller. In the paper the effectiveness of this type of control will be proved for a fault tolerant segmental stator SRM. By advanced simulation techniques the working principle of the direct instantaneous torque controlled drive system is illustrated, and its performances are demonstrated.

Keywords: Switched reluctance motor, segmental stator construction, direct instantaneous torque control, simulation.

\section{Introduction}

Beside high electrical and mechanical performances the fault tolerance is the main issue for electrical machines used in diverse safety-critical applications, as aerospace, automotive, military, medical, etc.).

The switched reluctance motor (SRM) due to its robust and simple construction and to the magnetic independence of its phases is inherently one of the most fault tolerant motors on the market [1]. Combining the fault tolerance increasing solutions cited in the literature [2], [3] and [4] with an innovative modular construction of its stator a novel SRM was developed, which is very reliable and quickly repairable. Its performances were improved by minimizing its torque ripples by estimating and controlling the developed instantaneous torque.

\section{The segmental stator SRM}

The stator of the proposed segmental stator SRM is built up of independent modules. Each one has an E-type iron core and a coil wound on its yoke. The modules corresponding to a phase are placed diametrically opposed in the stator. Between the neighboring modules a non-magnetic spacer is placed to assure the adequate shift of the modules and a good magnetic separation (see Fig. 1).

The four-phase variant has 8 stator modules. The entire segmental stator construction is tightened by 16 rods, 2 passing through each module. The stator is placed between two end shields. The conventional SRM rotor has 14 poles and it is built of laminations. The construction of the segmental stator SRM is given in Fig. 2.

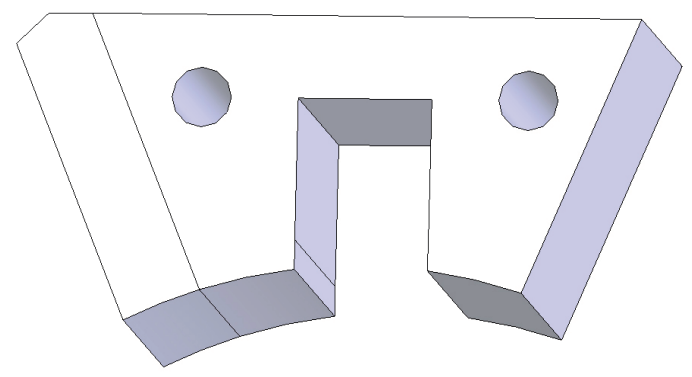

Fig. 1 The iron core of one module together with a spacer

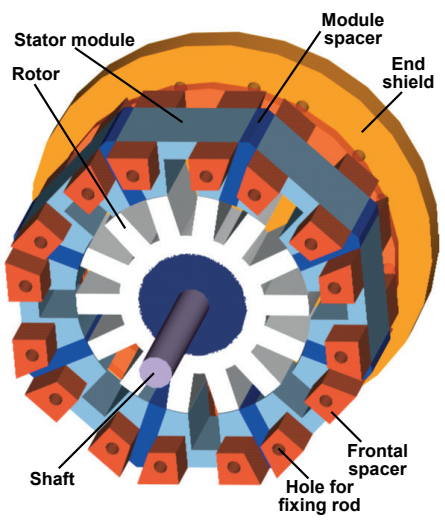

Fig. 2 The segmental stator SRM

\footnotetext{
* ${ }^{1}$ Lorand Szabo, ${ }^{1}$ Mircea Ruba, ${ }^{1}$ Daniel Fodorean, ${ }^{2}$ Pavol Rafajdus, ${ }^{2}$ Peter Dubravka

${ }^{1}$ Faculty of Electrical Engineering, Department of Electrical Machines and Drives, Technical University of Cluj-Napoca, Romania

${ }^{2}$ Faculty of Electrical Engineering, Department of Power Electrical Systems, University of Zilina, Slovakia

E-mail: Lorand.Szabo@emd.utcluj.ro; pavol.rafajdus@fel.uniza.sk
} 
The flux lines in the motor obtained by means of finite elements analysis (FEA) for unaligned and aligned positions are shown in Fig. 3 [5].

As it can be seen, the magnetic flux is closed between the two poles of a single module hence they are not passing through the central part of the rotor. Therefore, due to the shorter flux paths the losses in the machine are less than in a classical 4-phase SRM. Also due to this novel design the forces are better balanced in the machine [6].

One of the common fault tolerance increasing solutions is the division of the phases into individual coils, called channels [4], [7] and [8]. This way a fault of a channel will not influence the operation of the other channels of the same phase or of other phases. This solution was used also in the case of the

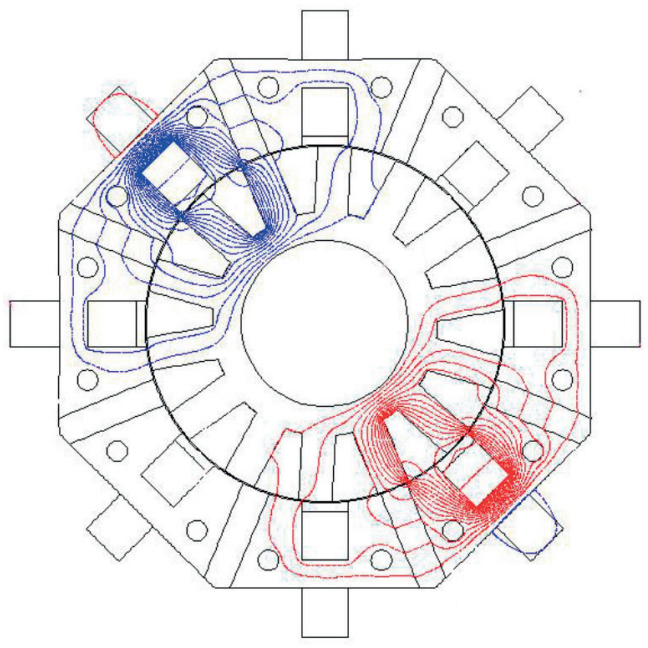

a) unaligned poles

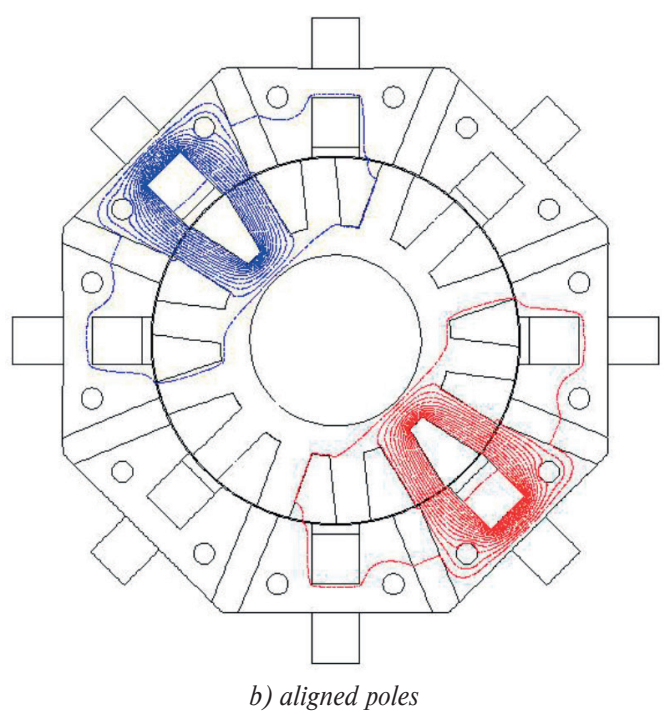

Fig. 3 The flux lines in the SRM in study obtained by means of numeric field computations segmental stator SRM in study. Hence, one phase of the machine is compound of two coils from diametrically opposed modules, connected in series or in parallel.

Due to the specific construction there is no mutual coupling between adjacent coils [6]. The drawback of this solution is that a more complex power converter is required, having as many converter legs as channels [9] and [10].

The adopted modular stator topology allows for an easy and quite low cost manufacturing, and assures the possibility of a fast replacement of a damaged module in case of a coil failure [5].

The main rated specifications of the sample segmental stator SRM taken into study are:

- power: $350 \mathrm{~W}$;

- current: $6 \mathrm{~A}$;

- average torque: $5 \mathrm{Nm}$.

\section{The direct instantaneous torque control}

One of the main disadvantages of the SRMs, and also of the particular segmental stator SRM in study, is their high torque ripple. These can generate significant undesired vibrations and noises.

In the literature several methods of SRM torque smoothening methods are cited [11] and [12] and [13]. These all require complex control [14] and [15], accurate torque and rotor position measurement [16], and complex current regulation techniques [17]. Current profiling [18] and [19] and torque sharing [20] and [21], methods are just two solutions that can be used for minimizing the SRM torque ripples.

A common conclusion can be drawn upon studying these methods, namely that as the complexity of the control strategy is increased, the losses in the SRM are also higher [22]. Therefore, a novel method was applied, the direct instantaneous torque control (DITC) [23], [24] and [25]. This has to be used where the losses have to be as low as possible, the system response has to be fast and accurate, and the generated torque must be very smooth [26].

The main advantage of the DITC is the lack of minor current loops, and of the precise tuning requirements of the PI or PID controllers. The torque is controlled directly by using a specific digital hysteresis controller. On the other hand, as the phase currents are not controlled, overheating of the power switches can occur. At high speeds, and when the currents are very high, the falling to nil of the current could be not enough fast and negative torques could be generated by a phase.

The instantaneous torque developed by the SRM needs to be known at each time step. Its precise measurement is difficult and expensive. A more effective approach is the estimation of the torque. In the literature basically four methods are cited for torque estimation. These methods are based on look-up tables, interpolation, analytical approach and artificial neural networks 
(ANN) [27], [28] and [29]. For the DITC method, the look-up table approach seems to be the best solution [23], [30] and [31].

For estimating the torque from the measured current and rotor position the static torque versus current and angular position is required. The values of this characteristic are stored in a 2D look-up table which can be obtained via measurements or FEA of the SRM [30] and [31]. Knowing at each time step the actual current and the rotor position, the torque of the SRM can be found by a simple looking in the table. It should be mentioned that separate look-up tables have to be computed for each SRM variant. The simplified block scheme of the DITC system of a SRM under study is given in Fig. 4 [13].

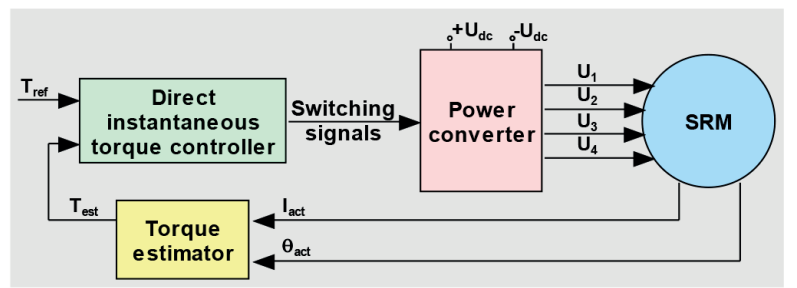

Fig. 4 The block scheme of the DITC system of a SRM [13]

\section{The DITC of the modular SRM}

The block diagram of the proposed DITC is given in Fig. 5 [32].

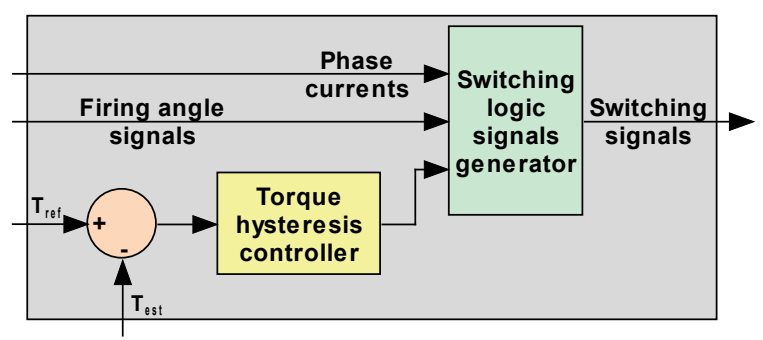

Fig. 5 The block scheme of the DITC [32]

The firing angles compared with the actual rotor position only indicate the conduction zones of the SRM. The main control tasks are performed by the torque hysteresis controller and the generator of switching logic signals. The torque controller uses two different hysteresis bands, one larger than the other. The control strategy follows the following rules:

1. while a single motor phase is active, the torque is controlled inside the main (the wider outer) hysteresis band;

2. during the phase commutation the torque control is performed as follows:

- for the formerly conducting phase the thinner hysteresis band is imposed;

- for the next phase the larger outer hysteresis band is prescribed;
3. after the end of the commutation period the torque will be again controlled within the outer hysteresis band.

Upon the actual value of the torque relatively to the two hysteresis bands the voltages of the phases are commutated by soft chopping between three values: $+V_{d c}, 0$, and $-V_{d c}$.

To simulate the DITC system an advance SRM model was built up. The simple, voltage equations based mathematical models [1] cannot be applied here, because of the necessity to integrate also the converter model and the DITC strategy. Therefore a more complex, FEA results based model was applied. For the sample SRM two look-up tables were built up upon the previously obtained FEA results [5], [33] and [34]. They contain the magnetic flux and the torque, respectively, versus the phase current and the rotor position. Upon the values from the two look-up tables two 3D static characteristics for one phase of the segmental stator SRM were plotted (see Fig. 6). The static characteristics of the magnetic flux are required only by the simulation program while that of the total torque both by the control strategy implementation and the DITC system model.

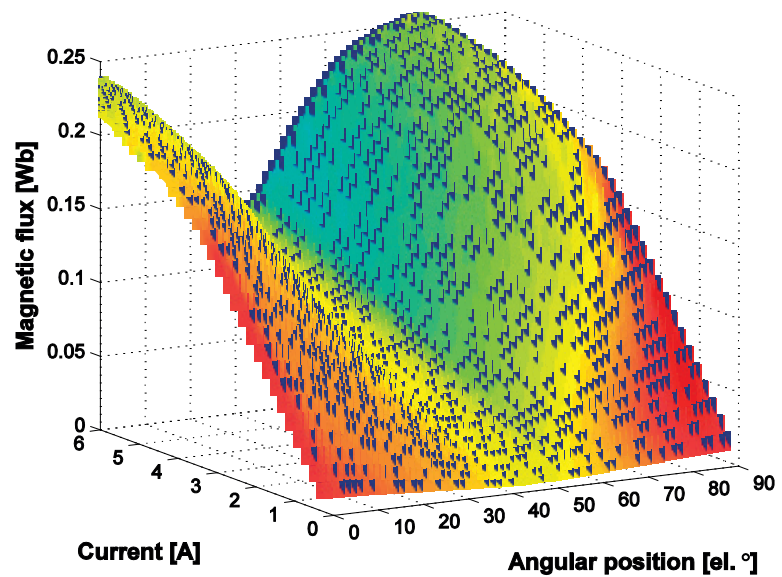

a) magnetic flux vs. phase current and rotor position

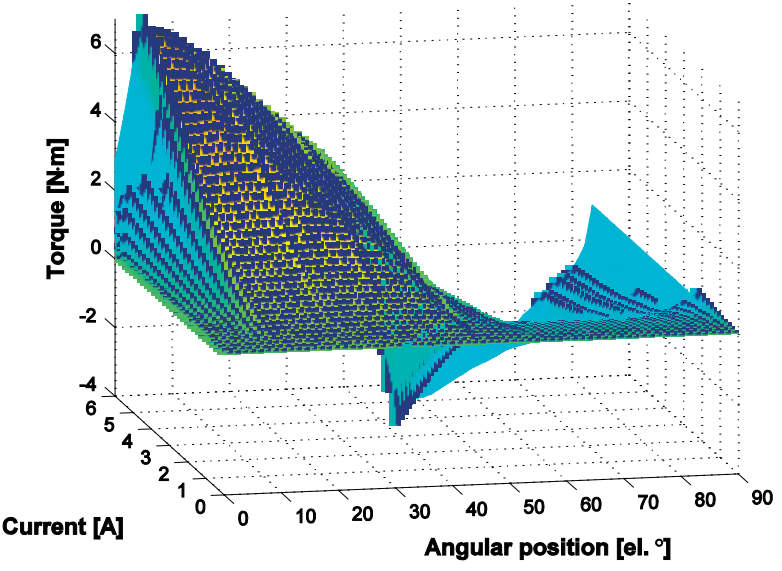

b) phase torque vs. phase current and rotor position

Fig. 6 The static characteristics of the segmental stator SRM 
The model of the DITC system controlled modular SRM was built up in the MATLAB $^{\circledR} /$ Simulink $^{\circledR}$ environment [34]. The main window of the simulation program is given in Fig. 7.

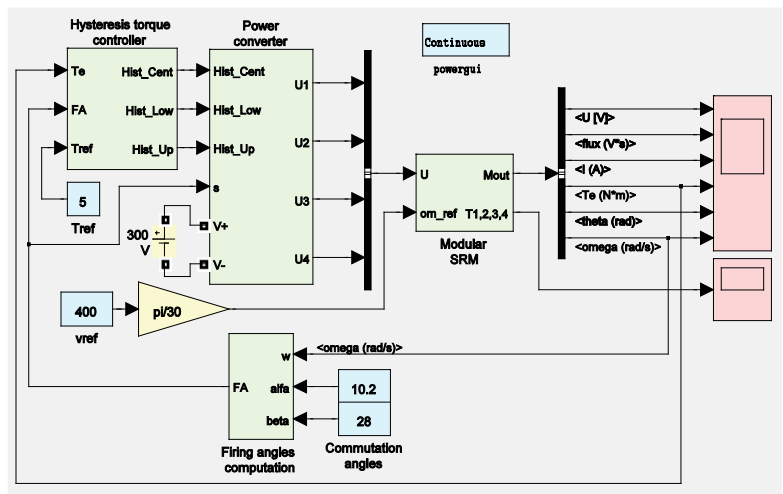

Fig. 7 The main window of the simulation program

The blocks modeling the hysteresis torque controller, the four-phase power converter, the modular SRM and the firing angle computation unit all can be easily distinguished in the modularly built up model.

The Hysteresis torque controller subsystem is using three Relay type blocks, as shown in Fig. 8. The maximum achievable frequency of the current controllers is $20 \mathrm{kHz}$.

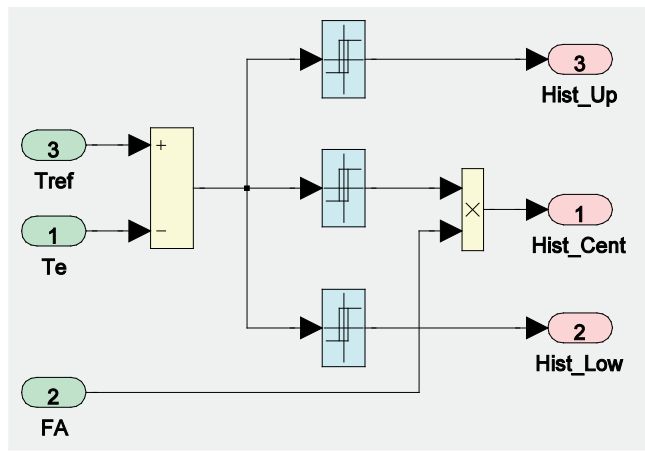

Fig. 8 The Hysteresis torque controller subsystem

The H-bridges of power converter were modeled by using blocks from the SimPowerSystems library of Simulink ${ }^{\circledR}$, as IGBT/ Diode, etc. [35].

The model of the motor is based mainly on the two 2D look-up tables, built up upon the static characteristics given in Fig. 6.

The simulations were performed under diverse conditions. Here some significant results obtained for the reference torque and speed of $4.5 \mathrm{~N} \cdot \mathrm{m}$ and $400 \mathrm{r} / \mathrm{min}$ are given.

In Fig. 9 the total torque, the imposed one and those developed by the four phases of the segmental stator SRM are given. As it can be seen the developed total torque is very close to the imposed $4.5 \mathrm{~N} \cdot \mathrm{m}$ reference value. The torque ripples (of
$12.45 \%)$ are much smaller than those obtained in the case of a classical controlled modular SRM (near 30\% [6]).
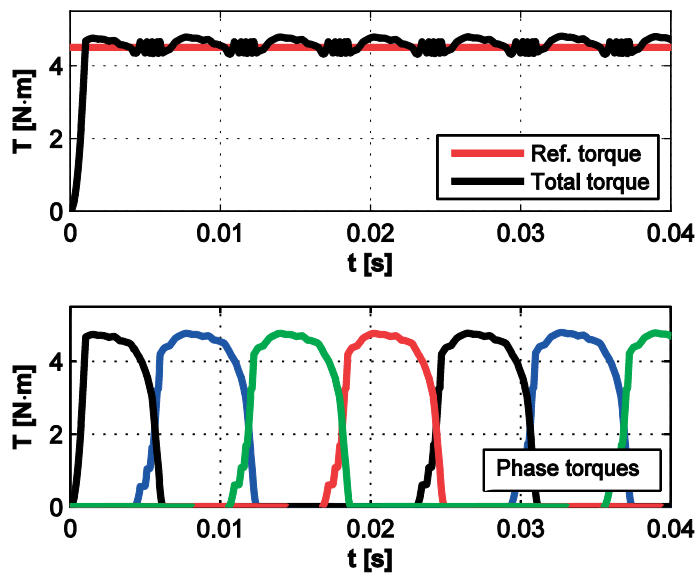

Fig. 9 Results of simulation: the total, the imposed and the phase torques developed by the segmental stator SRM
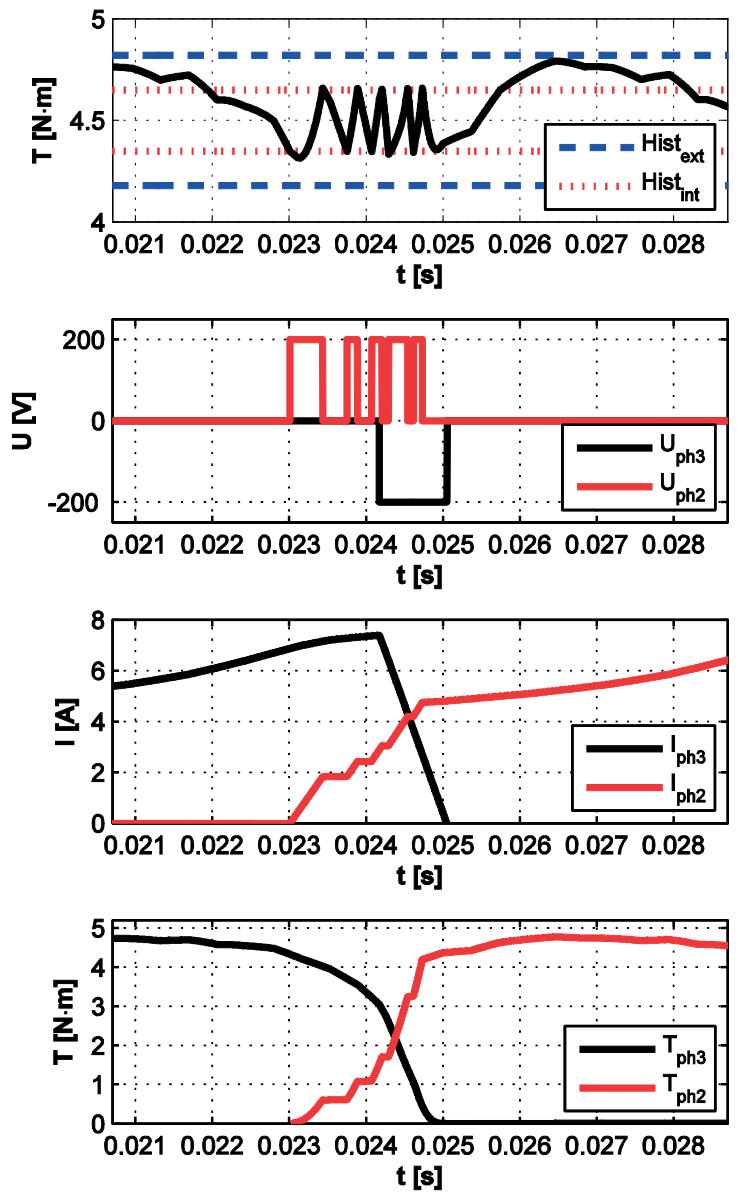

Fig. 10 Zoom of the results given in Fig. 9 showing the two hysteresis bands and the two phase voltages, currents and torques during a commutation 
In Fig. 10 a zoom of the results from Fig. 8 during a commutation are given. It can be clearly observed how the instantaneous torque is kept within one of the two (inner and outer) hysteresis bands, upon the developed control strategy. Also the way as the dc voltage is soft chopped between three values $\left(+V_{d c}, 0\right.$, and $\left.-V_{d c}\right)$ can be followed.

Before approximately $0.023 \mathrm{~s}$, while only phase 3 is in conduction, the torque is controlled inside the main (the outer) hysteresis band. During the phase commutation when usually the torque drops, the torque control is more severe since it is partially performed upon the thinner inner hysteresis band. For the period of commutation also the higher frequency of the voltage soft chopping is clearly visible. After the commutation took place, the torque is kept again within the outer inner hysteresis band.

During the commutation, due to the higher commutation frequency imposed, also the losses in the motor are higher. This is the reason for which the torque is controlled inside the inner hysteresis band only during the phase commutation, the most critical period for a low torque ripple.

\section{Conclusions}

The paper deals with the control of a fault tolerant SRM having a segmental stator specially designed for safety-critical applications.

The modular construction of the SRM simplifies both its manufacturing and repairing. The independent stator segments can be manufactured separately, and the entire stator can be easily assembled. The SRM can be quickly repaired if winding faults occur, without removing it from the load.

The fault tolerance of this SRM was proven in several previous papers [5] and [6]. Therefore, it can be used in diverse safety-critical applications in the fields of advanced automation systems, automotive, medical, aerospace, military, etc. [36], [37] and [38].
In such high demanding systems also the relatively great torque ripples of the SRMs could be an important drawback. Therefore a simple, but yet effective control approach was taken into study: the DITC technique. The principles of this strategy are detailed in the paper.

The control method has several advantages, as smooth torque generation, direct compensation of the inherent torque ripple during phase commutation, good steady state torque control accuracy, simplification of sets of control variables and reduction of tuning control variables. All these are emphasized in the paper by advanced simulations performed via a MATLAB ${ }^{\circledR}$ Simulink ${ }^{\circledR}$ model of the machine. The model was developed by using the static magnetic flux and torque characteristics versus current and rotor position, fetched from the FEA of the machine. The converter model was built up by using blocks from the SimPowerSystems library of Simulink ${ }^{\circledR}$.

The presented results prove the effectiveness of the proposed control method, and hopefully will help the specialists working in this field to deepen their understanding in advanced control of the SRMs.

Future works will include the fault tolerance study of the segmental stator SRM with the proposed DITC. The control strategy will be implemented on an advanced DSpace system for the laboratory model of the SRM. A real-time turn ON and OFF angle optimization will be also investigated, which hopefully will more smooth the torque. This way, the DITC method will be applicable on the entire speed range of the machine, even with the possibility to work at speeds above the rated one.

\section{Acknowledgment}

This work was supported in part by the Romanian National Authority for Scientific Research, CNDI-UEFISCDI, under PCCA project No. 191/2012 and under bilateral grant No. 647/2013 (in the framework of the "Romanian-Slovak Intergovernmental S\&T Cooperation Programme for 2013-2014”).

\section{References}

[1] HENNEBERGER, G., VIOREL, I. A.: Variable Reluctance Electrical Machines. Aachen : Shaker Verlag, 2001.

[2] GOPALAKRISHNAN, S., OMEKANDA, A. M., LEQUESNE, B.: Classification and Remediation of Electrical Faults in the Switched Reluctance Drive, IEEE Transactions on Industry Applications, vol. 42, No. 2, pp. 479-486, 2006

[3] RUBA, M., SZABO, L.: Fault Tolerant Electrical Machines. State of the Art and Future Directions, J. of Computer Science and Control Systems, vol. 1, No. 1, pp. 202-207, 2008.

[4] SCHRAMM, A., GERLING, D.: Evaluation and Comparison of Fault Tolerant Switched Reluctance Machines for a Specific Application, Proc. of the $9^{\text {th }}$ Spanish Portuguese Congress on Electrical Engineering (9 CHLIE), Marbella, 2004.

[5] RUBA, M., VIOREL, I. A., SZABO, L.: Modular Stator Switched Reluctance Motor for Fault Tolerant Drive Systems, IET Electric Power Applications, vol. 7, No. 3, pp. 159-169, 2013.

[6] SZABO, L., RUBA, M.: Segmental Stator Switched Reluctance Machine for Safety-critical Applications, IEEE Transactions on Industry Applications, vol. 48, No. 6, pp. 2223-2229, 2012. 
[7] HUSAIN, I., RADUN, A., NAIRUS, J.: Fault Analysis and Excitation Requirements for Switched Reluctance-generators, IEEE Transactions on Energy Conversion, vol. 17, No. 1, pp. 67-72, 2002.

[8] DING, W., LOU, J., LIU, L.: Improved Decoupled Model of Mutually Coupled Dual-channel SRM with Consideration of Magnetic Saturation in Dual-channel Operation, IET Electric Power Applications, vol. 7, No. 6, pp. 427-440, 2013.

[9] MARTÍNEZ, E., ANDRADA, P., BLANQUE, B., TORRENT, M., PERAT, J., SANCHEZ, J.: Environmental and Life Cycle Cost Analysis of a Switched Reluctance Motor, Proc. of the $18^{\text {th }}$ Intern. Conference on Electrical Machines (ICEM '2008), Vilamoura, 2008.

[10] SZABO, L., RUBA, M., FODOREAN, D.: Study on a Simplified Converter Topology for Fault Tolerant Motor Drives, Proc. of the $11^{\text {th }}$ Intern. Conference on Optimization of Electrical and Electronic Equipment (OPTIM '2008), Brasov, 2008, pp. 197-202.

[11] EVANGELINE, S. J., KUMAR, S. S.: Torque Ripple Minimization of Switched Reluctance Drives - A Survey, Proc. of the $5^{\text {th IET }}$ Intern. Conference on Power Electronics, Machines and Drives (PEMD '2010) Brighton, 2010.

[12] HUSAIN, I.: Minimization of Torque Ripple in SRM Drives, IEEE Transactions on Industrial Electronics, vol. 49, No. 1, pp. 28-39, 2002.

[13] SOZER, Y., HUSAIN, I., TORREY, D. A.: Advanced Control Techniques for Switched Reluctance Machine Drives in Emerging Applications, Proc. of the 2013 IEEE Energy Conversion Congress and Exposition (ECCE '2013), Denver, 2013, pp. 3776-3783.

[14] BAOMING, G., XIANGHENG, W., JINGPING, J.: Nonlinear Internal-model Control for Switched Reluctance Drive with Torque Ripple-free, Automatika, vol. 43, No. 1, pp. 2-13, 2002.

[15] NAVARDI, M. J., BABAGHORBANI, B., KETABI, A.: Efficiency Improvement and Torque Ripple Minimization of Switched Reluctance Motor using FEM and Seeker Optimization Algorithm, Energy Conversion and Management, vol. 78, No. 2, pp. 237 244, 2014.

[16] ISLAM, M. S., HUSAIN, J.: Torque-ripple Minimization with Indirect Position and Speed Sensing for Switched Reluctance Motors, IEEE Transactions on Industrial Electronics, vol. 47, No. 5, pp. 1126-1133, 2000.

[17] GOBBI, R., RAMAR, K.: Optimisation Techniques for a Hysteresis Current Controller to Minimise Torque Ripple in Switched Reluctance Motors, IET Electric Power Applications, vol. 3, No. 5, pp. 453-460, 2009.

[18] PETRUŞ, V., POP, A., MARȚIŞ, C., IANCU, V., GYSELINCK, J.: Direct Instantaneous Torque Control of SRMs Versus Current Profiling - Comparison Regarding Torque Ripple and Copper Losses, Proc. of the $12^{\text {th }}$ International Conference on Optimization of Electrical and Electronic Equipment (OPTIM '2010), Moieciu, 2012, pp. 366-372.

[19] MITRA, R., UDDIN, W., SOZER, Y., HUSAIN, I.: Torque Ripple Minimization of Switched Reluctance Motors using Speed Signal Based Phase Current Profiling, Proc. of the $3^{\text {rd }}$ Annual IEEE EnergyTech Conference, Cleveland, 2013, pp. 1-5.

[20] DOWLATSHAHI, M., NEJAD, S. M. S., AHN, J.-W.: Torque Ripple Minimization of Switched Reluctance Musing Modified Torque Sharing Function, Proc. of the 21'Iranian Conference on Electrical Engineering (ICEE '2013), Mashhad, 2013, pp. 1-6.

[21] SUN, J., BAI, F., LOU, W., SUN, F.: Direct Instantaneous Torque Control Combined with Torque Sharing Function Strategy for

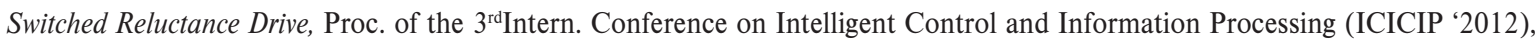
Dalian, 2012, pp. 386-389.

[22] SZABO, L., TEREC, R., RUBA, M., RAFAJDUS, P.: Reconfigurable Fault Tolerant Control System for Switched Reluctance Motors, Electrical and Power Engineering Frontier, vol. 1, No. 1, pp. 1-7, 2012.

[23] FUENGWARODSAKUL, N. H., DE DONCKER, R. W.: Instantaneous Torque Controller for Switched Reluctance Vehicle Propulsion Drives, Proc. of the $20^{\text {th }}$ Electric Vehicle Symposium (EVS-20), Long Beach, 2003.

[24] SUN, J., WANG, Y., BAI, F., SUN, F.: Simulation of the Direct Instantaneous Torque Control of SRM using MATLAB, Proc. of the Automatic Control and Artificial Intelligence Conference (ACAI '2012), Xiamen, 2012, pp. 1850-1853.

[25] SURYADEVARA, R., FERNANDES, B.G.: Modified Direct Instantaneous Torque Control of Switched Reluctance Motor with High Torque per Ampere and Reduced Source Current Ripple, Proc. of the $7^{\text {th }}$ Intern. Power Electronics Conference (IPEC-Hiroshima 2014 - ECCE-Asia), Hiroshima, 2014, pp. 2433-2437.

[26] RUBA, M., FODOREAN, D.: Design, Analysis and Torque Control of Low Voltage High Current SRM for Small Automotive Applications, Proc. of the IEEE Region 8 EUROCON Conference (EUROCON '2013), Zagreb, 2013, pp. 1498-1503.

[27] HUSAIN, T., ELRAYYAH, A., SOZER, Y., HUSAIN, I.: An Efficient Universal Controller for Switched-reluctance Machines, Proc. of the $28^{\text {th }}$ Annual IEEE Applied Power Electronics Conference and Exposition (APEC '2013), Long Beach, 2013.

[28] LIN, Z., REAY, D. S., WILLIAMS, B. W., HE, X.: On-line Torque Estimation in a Switched Reluctance Motor for Torque Ripple Minimisation, Proc. of the 2004 IEEE International Symposium on Industrial Electronics (ISIE '2004) Ajaccio, 2004, pp. 981-985.

[29] ST MANOLAS, I., KLADAS, A. G., MANIAS, S. N.: Finite-element-based Estimator for High-performance Switched Reluctance Machine Drives, IEEE Transactions on Magnetics, vol. 45, No. 3, pp. 1266-1269, 2009. 
[30] INDERKA, R. B., DE DONCKER, R. W., KREHENBRINK, M.: On-line Estimation of Instantaneous Torque in Switched Reluctance Machine Control, Proc. of the 2000 IEEE International Symposium on Industrial Electronics (ISIE '2000), Cholula, 2000, pp. 385-389.

[31] DUBRAVKA, P., RAFAJdUS, P., MAKYS, P., PENIAK, A., HRABOVCOVA, V., SZABO, L. et al.: Design of Fault Tolerant Control Technique for SRM Drive, Proc. of the $16^{\text {th }}$ European Conference on Power Electronics and Applications (EPE '2014-ECCE Europe), Lappeenranta, 2014, pp. 1-6.

[32] CASTRO, J., ANDRADA, P., BLANQUÉ, B.: Minimization of Torque Ripple in Switched Reluctance Motor Drives Using Direct Instantaneous Torque Control, Proc. of the Intern. Conference on Renewable Energies and Power Quality (ICREPQ '2012), Santiago de Compostela, 2012.

[33] JEONG, B., LEE, K., NA, J., CHO, G., BAEK, H.: Direct Torque Control for the 4-phase Switched Reluctance Motor Drives, Proc. of the $8^{\text {th }}$ Intern. Conference on Electrical Machines and Systems (ICEMS '2005), Nanjing, 2005, pp. 524-528.

[34] RAFAJdUS, P., SEKERAK, P., KAlAMEN, L., HRAbOVCOVA, V., CHEN, H.: Static and Dynamic Analysis of Linear Switched Reluctance Machine, Communications - Scientific Letters of the University of Zilina, vol. 4, pp. 6-11, 2011.

[35] SZABO, L., RUBA, M., FODOREAN, D., RAFAJDUS, P., DUBRAVKA, P.: Direct Instantaneous Torque Controlled Modular Switched Reluctance Motor Designed for Automotive Applications, Proc. of the $10^{\text {th }}$ Intern. Conference ELEKTRO 2014, Rajecke Teplice, 2014, pp. 239-244.

[36] HRABOVCOVA, V., RAFAJdUS, P., LIPTAK, M., SZABO, L.: Performance of Converters Suitable for Switched Reluctance Generator (SRG) Operation, J. of Electrical Engineering, vol. 64, No. 4, pp. 201-211, 2013.

[37] RAFAJdUS, P., DUBRAVKA, P., PENIAK, A., SAITZ, J., SZABO, L.: Design Procedure of Switched Reluctance Motor used for Electric CAD Drive, Proc. of the $22^{\text {nd }}$ Intern. Symposium on Power Electronics, Electrical Drives, Automation and Motion (SPEEDAM '2014), Ischia, 2014, pp. 112-117.

[38] DUBRAVKA, P., RAFAJdUS, P., MAKYS, P., HRABOVCOVA, V., SZABO, L.: Analysis of Switched Reluctance Behavior under Electrical Fault Conditions, Communications - Scientific Letters of the University of Zilina, vol. 2A, pp. 60-66, 2013. 